ISSN 1392-3196 / e-ISSN 2335-8947

Zemdirbyste-Agriculture, vol. 102, No. 3 (2015), p. 265-272

DOI $10.13080 / \mathrm{z}-\mathrm{a} .2015 .102 .034$

\title{
The effect of amino acids on nitrogen, phosphorus and potassium changes in spring barley under the conditions of water deficit
}

\author{
Irena PRANCKIETIENĖ, Edita MAŽUOLYTĖ-MIŠKINĖ, Viktoras PRANCKIETIS, \\ Rūta DROMANTIENĖ, Gvidas ŠIDLAUSKAS, Rimantas VAISVALAVIČIUS \\ Aleksandras Stulginskis University \\ Studentų 11, Akademija, Kaunas distr., Lithuania \\ E-mail: irena.pranckietiene@asu.lt
}

\begin{abstract}
Small plot experiments were conducted on an Endocalcaric Endohypogleyic Luvisol in Aleksandras Stulginskis University to determine the effect of different concentrations of amino acids on the dynamics of nitrogen, phosphorus and potassium in spring barley leaves and on grain productivity under the water deficit conditions. The following experimental design was used: factor A - different concentrations of amino acid solutions: the control (unsprayed), sprayed with water, sprayed with $0.5,1.0,1.5,1.5 \%$ with microelements and $2.0 \%$ amino acid solutions; factor $\mathrm{B}$ - time of fertilization with the amino acids: BBCH 21-23 and 26-29 growth stages. Topsoil moisture content decreased from $14.5 \%$ to $8.7 \%$ during the BBCH $21-49$ stages and thus it was considered as water deficiency conditions. The amino acid solutions of different concentrations, used for spring barley fertilization under the water deficiency conditions during the BBCH 21-23 or 26-29 stages, significantly increased the nitrogen, phosphorus and potassium content in the plants during the BBCH 26-29 and 32-35 stages in comparison to the control plants that were not sprayed with water. In many cases, the water spray stimulated nitrogen uptake to the same extent as amino acids application. Having analysed the effect of spring barley fertilization with the amino acids, it was found that the content of nitrogen did not reach the optimal level in the leaves of plants. However, the content of phosphorus reached the minimal limit of the optimal content at the BBCH 26-29 stage. A significant yield increase $\left(0.15-0.47 \mathrm{t} \mathrm{ha}^{-1}\right)$ was obtained when the spring barley had been fertilized with the $1.0 \%$ concentration of amino acids solution during the $\mathrm{BBCH} 21-23$ stage.
\end{abstract}

Key words: grain yield, growth stages, Hordeum vulgare, nutrients, topsoil moisture.

\section{Introduction}

A water stress is one of the most important growth limiting factors in the crop production (Genc et al., 2013). The plants experiencing drought stress make changes in some of their physiological and biochemical features (Keyvan, 2010). The drought stress has been reported to severely reduce germination and development of seedlings (Kaya et al., 2006). A plant response to the water stress depends mainly on the severity and duration of stress and growth stage of plants. Different physiological and biochemical processes are altered by the drought, such as gas exchange, photosynthesis and metabolism of carbohydrates (Pagter et al., 2005; Chaves et al., 2009). Environmental factors such as drought may cause nutrient deficiencies, even in fertilized fields, as physiochemical properties of soil can lead to a reduced mobility and absorbance of individual nutrients (Amtmann, Blatt, 2009). Most mineral nutrients are dependent on soil moisture to move through a soil matrix and be taken up by plants (Taiz, Zeiger, 2002). The drought causes a low nutrient availability in the soil and a lower nutrient transport in the plants (Hu et al., 2007). This leads to the nitrogen deficiency in the plant, which rapidly inhibits the plant growth and leads to a chlorosis (Mahieu et al., 2009). An early uptake of nitrogen under conditions of low moisture enhances both shoot and root development, which is critical to a final yield. About $50 \%$ of all the nitrogen in a leaf is involved in the photosynthesis as either enzymes or chlorophyll. The nitrogen supply improved photosynthesis capacity by increasing the leaf area and photosynthesis pigment content and enhancing photosynthetic efficiency under the water stress (Wu et al., 2008).

A good supply of water is required for phosphate availability and absorption by the plants. It was determined that phosphate ions move through the soil primarily through a diffusion and if the water content in the soil decreases, the radii of water-filled pores decrease, a tortuosity increases and the phosphorus mobility decreases (Faye et al., 2006). A drought decreases available phosphorus in the soil and transport in the plants. The phosphorus status in the soil is unreliable unless the plants have grown without a water stress for at least six weeks. Sardans and Peñuelas (2004) found that a $22 \%$ reduction in the soil moisture produced a $40 \%$ decrease in an accumulated above-ground $\mathrm{P}$ content in the plants. The positive effects 
of $\mathrm{P}$ on plant growth under drought have been attributed to an increase in stomatal conductance (Brück et al., 2000), photosynthesis, higher cell-membrane stability, root development (Chaves et al., 2009).

Water conditions in the plants influence potassium accumulation in the leaves and interact with a potassium nutritional status in some plant species (Restrepo-Diaz et al., 2008). The potassium ions help in an osmotic adjustment (Farooq et al., 2009). The potassium assists in an osmoregulation of cell, helps in opening and closing of stomata. A stomatal opening mechanism is governed by the potassium concentration (Taiz, Zeiger, 2002; Larcher, 2006). The opening and closure of potassium channels are of particular importance to guard the cells and this action mechanism is controlled by a reception of red light, which induces the stomatal opening. Mahouachi (2007) found reduced levels of potassium in the plants under the drought conditions.

Amino acids are a well-known biostimulant which has positive effects on the plant and the root growth, the yield and significantly mitigates injuries caused by abiotic stresses (Azimi et al., 2013). Low-molecular-weight osmolytes, including glycinebetaine, proline and the other amino acids, organic acids, and polyols, are crucial to sustain cellular functions under the drought (Farooq et al., 2009). Saeed et al. (2005) found that treatments of amino acids significantly improved growth parameters of soybean shoots and fresh weight as well as pod yield. The study results showed that the interaction effects of water deficit and time of spraying the amino acid on the number of rows per spike, number of grains per row, 1000 grain weight, grain yield, biological yield, harvest index, protein yield, protein percentage and proline were significant at a 5\% level (Kasraie et al., 2012).

The goal of the research was to determine the effect of different concentrations of amino acids on nitrogen, phosphorus and potassium dynamics in the leaves and grain yield of spring barley (Hordeum vulgare L.) cultivar 'Aura' as influenced by the water deficit conditions.

\section{Materials and methods}

Experiments. Small plot experiments were carried out in 2012 in the Experimental Station of Aleksandras Stulginskis University, Lithuania (5453' $\left.\mathrm{N}, 23^{\circ} 50^{\prime} \mathrm{E}\right)$. The soil of the experimental site is sandy loamy Endocalcaric Endohypogleyic Luvisol (World reference base..., 2014). The soil particle size distribution is presented in Table 1.

Table 1. Soil texture

\begin{tabular}{|c|c|c|c|c|}
\hline \multirow{2}{*}{$\begin{array}{l}\text { Horizon and } \\
\text { depth } \\
\mathrm{cm}\end{array}$} & \multicolumn{3}{|c|}{$\begin{array}{c}\text { Percentage share of fraction } \\
\mathrm{mm}\end{array}$} & \multirow[b]{2}{*}{ Texture class } \\
\hline & $\begin{array}{c}\text { sand } \\
(2- \\
0.063)\end{array}$ & $\begin{array}{c}\text { silt } \\
(0.063- \\
0.002)\end{array}$ & $\begin{array}{c}\text { clay } \\
(<0.002)\end{array}$ & \\
\hline Ap 0-23 & 66.1 & 19.8 & 14.1 & sandy loam \\
\hline AEl 23-42 & 63.4 & 20.6 & 16.0 & sandy loam \\
\hline El 42-58 & 59.2 & 25.8 & 15.0 & sandy loam \\
\hline Btkg 58-104 & 63.0 & 8.3 & 28.6 & sandy clay loam \\
\hline Ckg 104-150 & 68.4 & 20.7 & 10.9 & sandy loam \\
\hline
\end{tabular}

The main properties of the soil plough layer - Ap horizon: $\mathrm{pH}_{\mathrm{KCL}}$ 7.0, available phosphorus $\left(\mathrm{P}_{2} \mathrm{O}_{5}\right)$
- 106-108 mg kg-1, available potassium $\left(\mathrm{K}_{2} \mathrm{O}\right)-139$ $140 \mathrm{mg} \mathrm{kg}^{-1}$, mineral nitrogen $\left(\mathrm{N}^{-\mathrm{NO}_{3}^{-}}+\mathrm{N}^{-} \mathrm{NH}_{4}^{+}\right)-$ $10.2-10.5 \mathrm{mg} \mathrm{kg}^{-1}$, total nitrogen $(\mathrm{N})-0.13 \%$.

The experiments were done with a spring barley (Hordeum vulgare L.) cultivar 'Aura'. The experiment plots were covered with a polythene cover to avoid the rainfall; in addition, they were protected from the surface moisture with the insulation tapes. The covers and the insulation tapes were fitted during the $\mathrm{BBCH}$ 15-17 growth stage and were removed after the flag leaf sheath opening (BBCH 45-49 stage).

The experimental design was as follows: factor A - different concentrations of amino acids: the control (unsprayed), spring barley sprayed with water, fertilized with the solutions of amino acids of $0.5,1.0,1.5$ and $1.5 \%$ concentration with microelements $\mathrm{B}, \mathrm{Mn}, \mathrm{Zn}$ and with the solution of amino acids of $2.0 \%$ concentration (by an active ingredient); factor B - time of fertilization with the amino acids: BBCH 21-23 and 26-29 stages. The total volume of solution was $2001 \mathrm{ha}^{-1}$.

Soil moisture content decreased from $14.5 \%$ to $8.7 \%$ during the $\mathrm{BBCH} 21-49$ stages and, thus, it was considered as water deficiency conditions. The spring barley was sprayed with water and the different concentrations of amino acid solutions during the $\mathrm{BBCH}$ 21-23 stage, when the topsoil moisture was $14.52 \pm 1.92 \%$ and during the $\mathrm{BBCH} 26-29$ stage, when the topsoil moisture was $12.44 \pm 2.22 \%$. Topsoil water capacity was $45 \%$, and thus, respectively, the optimal topsoil water content should constitute $22.5-27.0 \%$, i.e. $50-60 \%$ from the topsoil water capacity (Šlapakauskas, Duchovskis, 2008). Soil moisture content at the BBCH 15-49 stages was measured 22 times at a depth of $0-25 \mathrm{~cm}$.

An amino acid product, consisting of $24.0 \%$ of $\alpha$ amino acids, $9.0 \%$ of total nitrogen, $5.3 \%$ of protein nitrogen, $37.0 \%$ of organic matter, $23.0 \%$ of organic carbon, was used in the experiment. The composition of $\alpha$ amino acids (\%): aspart (7.19), serine (7.09), glutamic (10.78), glycine (26.5), alanine (10.28), valine (2.4), methionine (0.9), isoleucine (2.1), leucine (4.89), tyrosine (3.19), histidine (0.4), lysine (2.5), arginine (2.79), threonine (2.2), phenylalanine (3.29), hydroxyproline (3.49), proline (10.48) and other (26.03) amino acids.

Before the spring barley sowing the soil was fertilized with a complex NPK 17-17-17 $\left(\mathrm{N}_{85} \mathrm{P}_{85} \mathrm{~K}_{85}\right)$ fertilizer; moreover, the plants were additionally fertilized with ammonium nitrate $\left(\mathrm{N}_{20}\right)$ during the tillering stage. Spring barley cultivar 'Aura' was grown in the experiment. Harvest plot area was $0.25 \mathrm{~m}^{2}$. The experiment was carried out in six replications. The plots were located randomly.

Plant analyses. To evaluate the effects of amino acids on the changes of nitrogen, phosphorus and potassium content in spring barley under the conditions of water deficit, plant samples were collected: at the BBCH 26-29, 32-35, 39-43 and 45-49 stages; when the spring barley had been fertilized at the $\mathrm{BBCH} 21-23$ stage and during the $\mathrm{BBCH}$ 32-35, 39-43 and 45-49 stages; when the spring barley had been fertilized at the BBCH 26-29 stage.

The content of nitrogen in the leaves of spring barley was established using the Kjeldahl method (LST EN ISO 5983-1:2005); the content of phosphorus - the spectrophotometry method; the content of potassium the atomic absorption spectrometry method. Optimal and critical nitrogen, phosphorus and potassium levels in plants were evaluated according to Havlin et al. (2005). 
Soil tests. Soil samples for agrochemical analysis were taken from the arable $(0-25 \mathrm{~cm})$ layer before the trial. The determined parameters: $\mathrm{pH}-$ by the potentiometric method (ISO 10390:1994), mobile phosphorus $\left(\mathrm{P}_{2} \mathrm{O}_{5}\right)$ and potassium $\left(\mathrm{K}_{2} \mathrm{O}\right)$ - by the EgnerRiem-Domingo (A-L) method (GOST 26208-91:1993), the total nitrogen $(\mathrm{N})$ - by the Kjeldahl method (ISO 11261:1995), the mineral nitrogen - by the colorimetric method, $1 \mathrm{~N} \mathrm{KCl}$ extract (ISO/TS 14256-1:2003).

Statistical analysis. The data were processed using computer software ANOVA (Tarakanovas, Raudonius, 2003) and STATISTICA 7 (Čekanavičius, Murauskas, 2009). The obtained data were evaluated statistically by calculating the least significant difference (LSD) at significance level of $P<0.05$ and the coefficients of regression $\eta$. The symbols * used in this work represent statistically significant at $95 \%$ probability level.

\section{Results and discussion}

The water deficit interferes not only with the photosynthesis, hormone balance, respiration, plant mineral nutrition through the roots; also, it disturbs transportation of nutritional elements and assimilates from one part of the plant to another. The amino acids were used in order to manage the negative effect on spring barley development caused by the water deficit. The amino acids are used for the synthesis of proteins, enzymes and hormones; also, for the transportation of mineral nutrition elements and other assimilates in the plant, in addition, the amino acids carry complexone and other functions. Research has shown that the content of asparago and glutamic acids in the plant affects nitrogen absorption intensity through the roots (Nikiforova et al., 2006). In addition, some studies showed that nitrogen supply minimizes the effects of drought on the plants. Under low moisture growing conditions, an early uptake of nitrogen enhances both shoot and root development which is critical to final yield formation.

The experiment showed that spring barley fertilized with $0.5-2.0 \%$ concentration of amino acid solutions during the BBCH 21-23 growth stage under the topsoil moisture deficiency conditions, 7 days after fertilization (BBCH 26-29 stage) had significantly more nitrogen, compared with the control plants (Table 2). A positive effect of $0.5-1.5 \%$ concentration of amino acid solutions on the nitrogen content remained, also, during the $\mathrm{BBCH} 32-35$ stage. Compared with the water sprayed plants, both during the BBCH 26-29 and 32-35 stages only $0.5 \%$ concentration of amino acid solutions gave a significant effect. During the BBCH $39-43$ and $45-49$ stages of spring barley, on the $21^{\text {st }}$ and $28^{\text {th }}$ day after fertilization no significantly positive effect of amino acids was established. The effect of the microelements on the nitrogen concentration was not significant.

Table 2. The effect of amino acids on nitrogen $(\mathrm{N})$ content in the above-ground part of spring barley, when the plants had been fertilized during the BBCH 21-23 growth stage under the topsoil moisture deficiency conditions

\begin{tabular}{lcccc}
\hline \multirow{2}{*}{ Treatment } & \multicolumn{4}{c}{ N content \% dry matter } \\
\cline { 2 - 5 } & BBCH 26-29 & BBCH 32-35 & BBCH 39-43 & BBCH 45-49 \\
\hline Control (unsprayed) & 2.50 & 2.35 & 2.03 & 1.64 \\
Sprayed with water & 3.68 & 2.45 & 1.90 & 1.63 \\
Amino acids 0.5\% & 3.81 & 2.72 & 2.08 & 1.63 \\
Amino acids 1.0\% & 3.58 & 2.52 & 1.87 & 1.59 \\
Amino acids 1.5\% & 3.64 & 2.50 & 1.70 & 1.62 \\
Amino acids 1.5\%+ B, Mn, Zn & 3.55 & 2.45 & 1.78 & 1.72 \\
Amino acids 2.0\% & 3.52 & 2.39 & 2.10 & 0.147 \\
\hline
\end{tabular}

The research showed a strong $(\eta=0.871)$ correlation between the amino acid concentrations and the nitrogen content during the $\mathrm{BBCH} 26-29$ stage, in other cases, the relationship between these variables was moderate $(\eta=0.667$ and 0.620$)$.

The spring barley, which had been growing for 10 days under the water deficit conditions, during the $\mathrm{BBCH}$ $26-29$ stage was fertilized with $0.5-2.0 \%$ concentration of amino acid solutions, after 7 days (BBCH 32-35 stage) the spring barley accumulated significantly $(0.12$ $0.20 \%$ unit) more nitrogen, compared with the control plants (Table 3). The effect of amino acids solutions under these conditions was significantly smaller, compared with that of water. The effect of different concentrations of amino acid solutions on the nitrogen accumulation did not significantly differ among each other. The correlation between the amino acid concentrations and the nitrogen content in the aboveground part of plants was strong $(\eta=0.709)$.

Table 3. The effect of amino acids on nitrogen $(\mathrm{N})$ content in the above-ground part of spring barley, when the plants had been fertilized during the BBCH 26-29 growth stage under the topsoil moisture deficiency conditions

\begin{tabular}{lccc}
\hline \multirow{2}{*}{ Treatment } & \multicolumn{3}{c}{ N content \% dry matter } \\
\cline { 2 - 4 } & BBCH 32-35 & BBCH 39-43 & BBCH 45-49 \\
\hline Control (unsprayed) & 2.34 & 2.04 & 1.58 \\
Sprayed with water & 2.99 & 2.35 & 1.82 \\
Amino acids 0.5\% & 2.55 & 1.83 & 1.70 \\
Amino acids 1.0\% & 2.47 & 1.77 & 1.58 \\
Amino acids 1.5\% & 2.48 & 1.89 & 1.71 \\
Amino acids 1.5\%+ B, Mn, Zn & 2.50 & 2.11 & 1.66 \\
Amino acids 2.0\% & 2.55 & 2.22 & 0.130 \\
\hline
\end{tabular}


The significant effect of amino acids on the nitrogen content in the plants was determined during later (BBCH 39-43 and 45-49) stages; it was established comparing the control and the water sprayed plants. It should be noted that spring barley sprayed with water during the $\mathrm{BBCH} 26-29$ stage under water deficiency conditions, accumulated the greatest contents of nitrogen during the $\mathrm{BBCH} 32-35,39-43$ and 45-49 stages. Aggregated data showed that the amino acids increased the nitrogen content in the spring barley on average for up to 7-14 days. However, the increase did not reach the optimal content of nitrogen needed in a particular stage. The spraying of water on the spring barley under the water deficit conditions stimulated the accumulation of nitrogen, in addition, in most cases the increase of nitrogen content was significant, compared with the control plants (Tables 2-3).

Under water deficit conditions an activation of phosphorus uptake by plants conditioned better development of both leaves and roots. A number of studies have shown that the addition of phosphorus alleviates the negative effect of drought stress on the yield. Phosphorus supply (20 mg kg-1 soil) increased dry matter of wheat shoot biomass in stressed plants $(53 \%$ field capacity) from 293 to $521 \mathrm{mg}^{\text {plant }}{ }^{-1}$ (Faye et al., 2006). During the experiment, under the water deficit conditions in order to increase the phosphorus content in the plants the amino acids were used, because under their effect the phosphorus uptake changed, in addition, this evidenced an increase in phosphoorganic compounds, which are involved in the energy conversion processes. As a result, the plants accumulated more sugar, also, the synthesis of nucleic acids increased.

The experimental data showed that the fertilization of spring barley with the amino acids during the water deficit period could have activated the phosphorus uptake. During the experiment, the spring barley was fertilized with $0.5-2.0 \%$ concentration of amino acid solutions during the $\mathrm{BBCH} 21-23$ stage and it accumulated a significantly higher content of phosphorus during the BBCH 26-49 stages, compared with the control and the plants sprayed with water (Table 4). A comparison of amino acid solutions showed that the biggest and significant increase of phosphorus content in the plants during the BBCH 26-29 stage was achieved when the spring barley had been fertilized with $1.5 \%$ and $2.0 \%$ concentration of solutions. The significant increase of phosphorus content in the plants during the $\mathrm{BBCH} 32-35$ and 39-43 stages was determined when the $2.0 \%$ concentration of solution had been used. During the BBCH 26-29 stage under the amino acid effect the content of phosphorus in plants reached the minimal optimal limit.

Table 4. The effect of amino acids on phosphorus (P) content in the above-ground part of spring barley, when the plants had been fertilized during the BBCH 21-23 growth stage under the topsoil moisture deficiency conditions

\begin{tabular}{|c|c|c|c|c|}
\hline \multirow{2}{*}{ Treatment } & \multicolumn{4}{|c|}{$\mathrm{P}$ content $\%$ dry matter } \\
\hline & ВBCH 26-29 & $\mathrm{BBCH} 32-35$ & BBCH 39-43 & $\mathrm{BBCH} 45-49$ \\
\hline Control (unsprayed) & 0.363 & 0.290 & 0.230 & 0.191 \\
\hline Sprayed with water & 0.385 & 0.249 & 0.214 & 0.206 \\
\hline Amino acids $0.5 \%$ & 0.408 & 0.308 & 0.282 & 0.229 \\
\hline Amino acids $1.0 \%$ & 0.429 & 0.354 & 0.271 & 0.244 \\
\hline Amino acids $1.5 \%$ & 0.434 & 0.333 & 0.272 & 0.246 \\
\hline Amino acids $1.5 \%+\mathrm{B}, \mathrm{Mn}, \mathrm{Zn}$ & 0.446 & 0.341 & 0.242 & 0.236 \\
\hline Amino acids $2.0 \%$ & 0.449 & 0.394 & 0.297 & 0.248 \\
\hline $\mathrm{LSD}_{05}$ & 0.016 & 0.014 & 0.011 & 0.022 \\
\hline
\end{tabular}

The correlation and regression analysis showed that there was significant and very strong relationship between the phosphorus content in the plants during the $\mathrm{BBCH} 26-29$ and 32-35 stages and the concentrations of amino acid solutions, in addition, there was a strong relationship between the phosphorus content during the BBCH 39-43 and 45-49 stages, on the $21^{\text {st }}$ and the $28^{\text {th }}$ day after fertilization (Table 5).

Table 5. The dependence of phosphorus (P) content (y) in the above-ground part of spring barley on the concentration ( $\mathrm{x}$ ) of amino acids under the topsoil moisture deficiency conditions

\begin{tabular}{ccc}
\hline $\begin{array}{c}\text { Growth stage } \\
(\mathrm{y})\end{array}$ & Regression equation & $\begin{array}{c}\text { Correlation } \\
\text { coefficient }\end{array}$ \\
\hline BBCH 26-29 & $\mathrm{y}=0.3656+0.0832 \mathrm{x}-0.0217 \mathrm{x}^{2}$ & $\eta=0.986^{*}$ \\
\hline BBCH 32-35 & $\mathrm{y}=0.2919+0.0357 \mathrm{x}+0.0054 \mathrm{x}^{2}$ & $\eta=0.909 *$ \\
\hline BBCH 39-43 & $\mathrm{y}=0.2396+0.0488 \mathrm{x}-0.012 \mathrm{x}^{2}$ & $\eta=0.788$ \\
\hline BBCH 45-49 & $\mathrm{y}=0.1933+0,0748 \mathrm{x}-0.0243 \mathrm{x}^{2}$ & $\eta=0.866$ \\
\hline * statistically significant $(P<0.05)$ coefficients
\end{tabular}

The solutions of amino acids (0.5-1.5\% concentration) were more effective when the spring barley had been fertilized with the amino acids during the $\mathrm{BBCH}$ 26-29 stage under the topsoil moisture deficiency conditions (Table 6). The plants accumulated significantly more phosphorus during the BBCH 32-35 stage, when spring barley had been fertilized with $1.0 \%$ and $1.5 \%$ concentration of solutions, compared with the water sprayed plants and the control plants. A positive significant effect on the phosphorus accumulation from $0.5 \%$ and $1.0 \%$ concentration of solutions remained during the $\mathrm{BBCH} 39-43$ and 45-49 stages, compared only with the control plants. The strong $(\eta=0.772)$ correlation relationships were determined between the amino acid concentrations and the phosphorus content during the $\mathrm{BBCH} 32-35$ stage. It was best described by a quadratic equation: $y=0.2751+0.1214 x-0.0564 x^{2}$. The phosphorus content during the $\mathrm{BBCH} 39-43$ and $45-49$ stages was moderate $(\eta=0.511$ and $\eta=0.569)$ and depended on the concentrations of solution used.

The water deficit caused physiological changes in plants. The potassium was directly involved in stomata opening, which was why its deficiency may have 
Table 6. The effect of amino acids on phosphorus (P) content in the above-ground part of spring barley, when the plants had been fertilized during the $\mathrm{BBCH} 26-29$ growth stage under the topsoil moisture deficiency conditions

\begin{tabular}{|c|c|c|c|}
\hline \multirow{2}{*}{ Treatment } & \multicolumn{3}{|c|}{$\mathrm{P}$ content $\%$ dry matter } \\
\hline & BBCH 32-35 & BBCH 39-43 & BBCH 45-49 \\
\hline Control (unsprayed) & 0.286 & 0.233 & 0.197 \\
\hline Sprayed with water & 0.303 & 0.318 & 0.230 \\
\hline Amino acids $0.5 \%$ & 0.291 & 0.320 & 0.236 \\
\hline Amino acids $1.0 \%$ & 0.368 & 0.282 & 0.236 \\
\hline Amino acids $1.5 \%$ & 0.324 & 0.243 & 0.227 \\
\hline Amino acids $1.5 \%+\mathrm{B}, \mathrm{Mn}, \mathrm{Zn}$ & 0.263 & 0.221 & 0.203 \\
\hline Amino acids $2.0 \%$ & 0.291 & 0.265 & 0.205 \\
\hline $\mathrm{LSD}_{05}$ & 0.009 & 0.022 & 0.014 \\
\hline
\end{tabular}

resulted in an excess of oxygen content, insufficiency of $\mathrm{CO}_{2}$, therefore, it may have resulted in a decrease of photosynthetic rate (Diaz et al., 2005). In addition, transportation of organic matter in the plant depended on the potassium content. The amino acids used in the experiment increased the potassium content in the plant. The significant increase of potassium content in the spring barley during the $\mathrm{BBCH}$ 26-29 stage, compared with the control plants, was influenced by $0.5-2.0 \%$ of concentration of amino acid solutions, which had been used for the fertilization of plants during the BBCH 21-
23 stage (Table 7). However, comparison with the water sprayed plants did not show the significant effect of amino acids. Later (during the BBCH 32-35 and 39-43 stages), there were recorded significant increases of potassium, compared with all the concentrations of solutions used, also, compared with the water sprayed and with the control plants. The highest contents of potassium and the significant increases during the $\mathrm{BBCH} 45-49$ stage were in the spring barley, fertilized with $1.5 \%$ and $2.0 \%$ concentration of solutions, compared with the control and water sprayed plants.

Table 7. The effect of amino acids on potassium (K) content in the above-ground part of spring barley, when the plants had been fertilized during the BBCH 21-23 growth stage under the topsoil moisture deficiency conditions

\begin{tabular}{lcccc}
\hline \multirow{2}{*}{$\begin{array}{c}\text { Concentration of amino acids } \% \\
\text { (factor A) }\end{array}$} & \multicolumn{4}{c}{ K content \% dry matter } \\
\cline { 2 - 5 } & BBCH 26-29 & BBCH 32-35 & BBCH 39-43 & BBCH 45-49 \\
\hline Control (unsprayed) & 5.13 & 4.07 & 3.30 & 2.10 \\
Sprayed with water & 5.56 & 4,08 & 3,26 & 2.18 \\
Amino acids 0.5\% & 5.65 & 4.99 & 3.70 & 2.34 \\
Amino acids 1.0\% & 5.51 & 4.72 & 3.53 & 2.34 \\
Amino acids 1.5\% & 5.55 & $4.67 *$ & 3.46 & 2.41 \\
Amino acids 1.5\%+ B, Mn, Zn & 5.43 & 4.46 & 3.61 & 2.19 \\
Amino acids 2.0\% & 5.53 & 4.45 & 3.98 & 2.56 \\
\hline
\end{tabular}

The spring barley fertilized with the amino acids during the $\mathrm{BBCH}$ 26-29 stage accumulated significantly more potassium during the $\mathrm{BBCH} 32-35$ stage, when there had been used $2.0 \%$ and $1.5 \%$ of concentration of solutions with the micro elements, compared with the control and the water sprayed plants (Table 8). Very strong $(\eta=0.961 *)$ correlation relationships between the concentrations of amino acids and the potassium content in the plant were established, the relationships were described by the quadratic equation: $\mathrm{y}=4.1146+0.0977 \mathrm{x}$ $+0.0571 \mathrm{x}^{2}$. A positive residual effect of the amino acids remained during the $\mathrm{BBCH} 45-49$ stage having used $0.5-2.0 \%$ of concentration of solutions, compared with the control plants. In addition, no significant effect was determined, compared with the water sprayed plants.

Table 8. The effect of amino acids on potassium (K) content in the above-ground part of spring barley, when the plants had been fertilized during the $\mathrm{BBCH} 26-29$ growth stage under the topsoil moisture deficiency conditions

\begin{tabular}{lccc}
\hline \multirow{2}{*}{ Treatment } & \multicolumn{3}{c}{ K content \% dry matter } \\
\cline { 2 - 4 } & BBCH 32-35 & BBCH 39-43 & BBCH 45-49 \\
\hline Control (unsprayed) & 4.09 & 3.39 & 2.02 \\
Sprayed with water & 4.33 & 3.93 & 2.17 \\
Amino acids 0.5\% & 4.24 & 4.11 & 2.49 \\
Amino acids 1.0\% & 4.23 & 3.19 & 2.28 \\
Amino acids 1.5\% & 4.38 & 3.52 & 2.30 \\
Amino acids 1.5\%+ B, Mn, Zn & 4.63 & 3.75 & 2.14 \\
Amino acids 2.0\% & 4.55 & 3.74 & 2.45 \\
\hline
\end{tabular}


Moisture stress in cereals depends on different developmental stage and it could significantly affect yield and other physiological traits. In arid and semiarid regions, wheat crops usually encounter drought during the grain filling period, which reduces grain yield dramatically (Sanjari et al., 2008). Yield is reduced mostly when drought stress occurs during the heading or flowering and soft dough stages (Gholamin et al., 2010). Bray et al. (2000) reported that the relative decreases in potential maximum crop yields (i.e. yields under ideal conditions), associated with abiotic stress factors including drought, vary between $54 \%$ and $82 \%$.

The productivity of spring barley was found to be highly depended on the soil moisture regime during the tillering and the booting stages. The spring barley produced on average 2.5 times lower yield at the $14.5-8.7 \%$ soil moisture during the $\mathrm{BBCH} 21-49$ stages, compared with the yield under conventional conditions $\left(4.4 \mathrm{t} \mathrm{ha}^{-1}\right)$. Under these conditions the productivity of grains in all the treatments differed from 1.40 to $1.87 \mathrm{t} \mathrm{ha}^{-1}$ (Table 9). The amino acids increased the productivity of spring barley grains by on average $6.3 \%$ to $16.7 \%$, compared with the control and from $4.5 \%$ to $5.0 \%$, compared with the water-sprayed plants. The biggest yield increases $\left(0.27-0.29 \mathrm{t} \mathrm{ha}^{-1}\right)$ of spring barley were obtained when it had been fertilized with the
$1.0 \%$ concentration of solution of amino acids during the BBCH 21-23 stage, compared with the water sprayed, the control plants and with the plants which had been fertilized with other different concentrations of amino acids solution.

Smaller, but, also, significant yield increases were obtained when the spring barley was fertilized with the $2.0 \%$ concentration of solution of amino acids and with the $1.5 \%$ concentration of solution of amino acids in combination with the microelements.

The spring barley fertilized with the amino acids during the $\mathrm{BBCH} 26-29$ stage produced by on average $0.14 \mathrm{t} \mathrm{ha}^{-1}$ smaller yield, compared with the plants fertilized during the $\mathrm{BBCH} 21-23$ stage. In this case, the best result $\left(1.72 \mathrm{tha}^{-1}\right)$ was obtained when the plants were fertilized with the $0.5 \%$ concentration of solution of amino acids. In addition, the yield increase was significant, compared with the control plants and with the plants which had been fertilized with other different concentrations of solution of amino acids. A comparison of all the obtained data of grain productivity showed that during the $\mathrm{BBCH} 21-49$ stages and at a decrease of soil moisture (from $14.55 \%$ to $9.0 \%$ ) it was more appropriate to fertilize the spring barley with the $1.0 \%$ concentration of solution of amino acids during the BBCH 21-23 instead of BBCH 26-29 stages.

Table 9. The effect of amino acids on the grain yield of spring barley

\begin{tabular}{|c|c|c|c|}
\hline \multirow{2}{*}{$\begin{array}{c}\text { Concentration of amino acids } \% \\
\text { (factor } \mathrm{A})\end{array}$} & \multicolumn{2}{|c|}{ Time of fertilization (factor B) } & \multirow{2}{*}{ Average of factor $A$} \\
\hline & BBCH 21-23 & BBCH 26-29 & \\
\hline Control (unsprayed) & 1.58 & 1.40 & 1.49 \\
\hline Sprayed with water & 1.60 & 1.56 & 1.58 \\
\hline Amino acids $0.5 \%$ & 1.60 & 1.72 & 1.66 \\
\hline Amino acids $1.0 \%$ & 1.87 & 1.69 & 1.78 \\
\hline Amino acids $1.5 \%$ & 1.60 & 1.57 & 1.58 \\
\hline Amino acids $1.5 \%+\mathrm{B}, \mathrm{Mn}, \mathrm{Zn}$ & 1.68 & 1.68 & 1.68 \\
\hline Amino acids $2.0 \%$ & 1.68 & 1.51 & 1.63 \\
\hline \multirow[t]{2}{*}{ Average of factor B } & 1.66 & 1.59 & \\
\hline & $.025, \quad \mathrm{LSD}_{05}$ & $\mathrm{LSD}_{05(\mathrm{~A} \times \mathrm{B})}=0$ & \\
\hline
\end{tabular}

The correlation regression analysis showed that the dependence of productivity of spring barley grains on the concentrations of amino acid solution was moderate and strong. These relationships are best described by the second degree regression equation: $\mathrm{y}_{(\mathrm{BBCH} 21-23)}=1.5833+0.258 \mathrm{x}-0.1133 \mathrm{x}^{2}, \eta=0.535$ and $\mathrm{y}_{(\mathrm{BBCH} 26-29)}=1.5055+0.2893 \mathrm{x}-0.1145 \mathrm{x}^{2}, \eta=0.868$.

Scientific literature suggests that the productivity of plants is linearly correlated with total plant nitrogen (Sinclair, Jamieson, 2006). In the experiment, the effect of nitrogen on the yield was weak $(\eta=0.41)$ and moderate $(\eta=0.69)$ under moisture deficit conditions.

When the topsoil moisture was decreasing from $14.52 \%$ to $9.0 \%$ during the $\mathrm{BBCH} 21-49$ stages, the productivity of spring barley grains was more dependent on the phosphorus content in the plants. During the tillering and the booting stages the content of phosphorus in the plants was responsible for $17.5-39.0 \%$ of grain yield. Potassium content in plants was responsible for $11-36 \%$ of the productivity.

\section{Conclusions}

1. The amino acid solutions of different (0.5-2.0\%) concentration, used for the fertilization of spring barley under the conditions of topsoil moisture deficiency during the BBCH 21-23 and 26-29 growth stages, significantly increased nitrogen content in plants 7 (BBCH 26-29 stage) and 14 (BBCH 32-35 stage) days after application. The nitrogen content, as influenced by the amino acids, increased in the spring barley, however, it did not reach the optimal level. The spray of spring barley with water during the water deficit period stimulated the uptake of nitrogen and in most cases the effect of water was equal to that of amino acids.

2. The spring barley, fertilized with $0.5-2.0 \%$ concentration of amino acid solutions during the $\mathrm{BBCH} 21-23$ stage, accumulated significantly higher phosphorus content during the $\mathrm{BBCH} 26-49$ stages, compared both with the control and the water sprayed plants. The content of phosphorous reached the optimal 
level during the $\mathrm{BBCH} 26-35$ stages due to the amino acids application. A lower concentration (0.5-1.5\%) of amino acid solutions was more effective during the BBCH 26-29 stage. The phosphorus reached the optimal content in the plants as influenced by the amino acids application during the $\mathrm{BBCH} 32-35$ stage.

3. The amino acid solutions of $0.5-2.0 \%$ concentration, used for the fertilization of spring barley under the conditions of topsoil moisture deficiency during the $\mathrm{BBCH} 21-23$ stage, increased the potassium content in the spring barley during later (BBCH 26-43) growth stages on average from $9.5 \%$ to $13.1 \%$ as compared with the water sprayed and control plants. Amino acids, used for the fertilization of spring barley during the $\mathrm{BBCH} 26-$ 29 stage, increased the content of potassium in the plants only during the $\mathrm{BBCH} 32-35$ stage. A significant increase of potassium content in the above-ground part of spring barley was determined when $1.5-2.0 \%$ concentration of solution had been applied, compared with the control and water sprayed plants.

4. When the topsoil moisture varied from $14.5 \%$ to $8.7 \%$ during the $\mathrm{BBCH} 21-49$ stages of spring barley, the amino acids solution $0.5-2.0 \%$ concentration increased the grain productivity by up to $14.7 \%$. The highest grain productivity $\left(1.87 \mathrm{t} \mathrm{ha}^{-1}\right)$ and a significant yield increase $\left(0.15-0.47 \mathrm{t} \mathrm{ha}^{-1}\right)$ were obtained when the spring barley had been fertilized with $1.0 \%$ concentration of amino acids solution during the $\mathrm{BBCH} 21-23$ stage.

Received 15122014

Accepted 19062015

\section{References}

Amtmann A., Blatt M. R. 2009. Regulation of macronutrient transport. New Phytologist, 181 (1): 5-52 http://dx.doi.org/10.1111/j.1469-8137.2008.02666.x

Azimi M. S., Daneshian J., Sayfzadeh S., Zare S. 2013. Evaluation of amino acid and salicylic acid application on yield and growth of wheat under water deficit. International Journal of Agriculture and Crop Sciences, 5 (8): 816-819 IJACS/2013/5-8/816-819

Bray E. A., Bailey-Serres J., Weretilnyk E. 2000. Responses to abiotic stresses. Buchanan B. B. et al. (eds.). Biochemistry and molecular biology of plants, p. 1158-1203

Brück H., Payne W. A., Sattelmacher B. 2000. Effects of phosphorus and water supply on yield, transpirational water-use efficiency, and carbon isotope discrimination of pearl millet. Crop Science, 40 (1): 120-125 http://dx.doi.org/10.2135/cropsci2000.401120x

Chaves M. M., Flexas J., Pinheiro C. 2009. Photosynthesis under drought and salt stress: regulation mechanisms from whole plant to cell. Annals of Botany, 103 (4): 551-560 http://dx.doi.org/10.1093/aob/men125

Čekanavičius V., Murauskas G. 2009. Statistika ir jos taikymai. Vilnius, 239 p. (in Lithuanian)

Diaz P., Borsani O., Marquez O., Monza J. 2005. Nitrogen metabolism in relation to drought stress responses in cultivated and model Lotus species. Lotus Newsletter, 35 (1): $125-134$

Farooq M., Wahid A., Kobayashi N., Fujita D., Basra S. M. A. 2009. Plant drought stress: effects, mechanisms and management. Agronomy for Sustainable Development, 29 (1): $185-212$

http://dx.doi.org/10.1051/agro:2008021
Faye I., Diouf O., Guisse A., Sene M., Diallo N. 2006. Characterizing root responses to low phosphorus in pearl millet (Pennisetum glaucum L.). Agronomy Journal, 98 (5): $1187-1194$ http://dx.doi.org/10.2134/agronj2005.0197

Genc L., Inalpulat M., Kizil U., Mirik M., Smith S., Mendes M. 2013. Determination of water stress with spectral reflectance on sweet corn (Zea mays L.) using classification tree (CT) analysis. Zemdirbyste-Agriculture, 100 (1): 81-90 http://dx.doi.org/10.13080/z-a.2013.100.011

Gholamin R., Zaeifizadeh M., Khayatnezhad M., Jamaati-eSomarin S., Zabihi-e-Mahmoodabad R. 2010. Study of drought tolerance in durum wheat genotypes. AmericanEurasian Journal of Agricultural and Environmental Sciences, 9 (5): 465-469

Havlin J. L., Beaton J. D., Tisdale S. L., Nelson W. L. 2005. Soil fertility and fertilizers an introduction to nutrient management ( $7^{\text {th }}$ ed.)

Hu Y., Burucs Z., Tucher S. V., Shmidhalter U. 2007. Shortterm effects of drought and salinity on mineral nutrient distribution along growing leaves of maize seedlings. Environmental and Experimental Botany, 60 (2): 268-275 http://dx.doi.org/10.1016/j.envexpbot.2006.11.003

Kaya M. D., Okcu G., Atak M. 2006. Seed treatments to overcome salt and drought stress during germination in sunflower (Helianthus annuus L.). European Journal of Agronomy, 24 (4): 291-295 http://dx.doi.org/10.1016/j.eja.2005.08.001

Kasraie P., Nasri M., Khalatbari M. 2012. The effects of time spraying amino acid on water deficit stress on yield, yield component and some physiological characteristics of grain corn (TWC647). Annals of Biological Research, 3 (9): $4282-4286$

Keyvan S. 2010. The effects of drought stress on yield, relative water content, proline, soluble carbohydrates and chlorophyll of bread wheat cultivars. Journal of Animal and Plant Sciences, 8 (3): 1051-1060

Larcher W. 2006. Physiological plant ecology (4 ${ }^{\text {th }}$ ed.). São Carlos, Brazilia, $550 \mathrm{p}$.

Mahieu S., Germon F., Aveline A., Hauggaard-Nielsen H., Ambus P., Jensen E. S. 2009. The influence of water stress on biomass and $\mathrm{N}$ accumulation, $\mathrm{N}$ portioning between above and below ground parts and on $\mathrm{N}$ rhizodeposition during reproductive growth of pea (Pisum sativum L.). Soil Biology and Biochemistry, 41 (2): 380-387 http://dx.doi.org/10.1016/j.soilbio.2008.11.021

Mahouachi J. 2007. Growth and mineral nutrient content of developing fruit on banana plants (Musa acuminata AAA, 'Grand Nain') subjected to water stress and recovery. Journal of Horticultural Science and Biotechnology, 82 (6): 839-844

Nikiforova V. J., Bielecka M., Gakiere B., Krueger S., Rinder J., Kempa S. 2006. Effect of sulfur availability on the integrity of amino acid biosynthesis in plants. Amino Acids, 30 (2): 173-183 http://dx.doi.org/10.1007/s00726-005-0251-4

Pagter M., Bragato C., Brix H. 2005. Tolerance and physiological responses of Phragmites australis to water deficit. Aquatic Botany, 81 (4): 285-299 http://dx.doi.org/10.1016/j.aquabot.2005.01.002

Restrepo-Diaz H., Benlloch M., Fernandez-Escobar R. 2008. Plant water stress and $\mathrm{K}^{+}$starvation reduce absorption of foliar applied $\mathrm{K}^{+}$by olive leaves. Scientia Horticulturae, 116 (4): 409-413 http://dx.doi.org/10.1016/j.scienta.2008.03.004

Saeed M. R., Kheir A. M., Al-Sayed A. A. 2005. Supperssive effect of some amino acids against Meloidogyne incognita on soybeans. Journal of Agricultural Sciences, 30 (2): $1097-1103$ 
Sanjari A., Pireivatlo U., Yazdansepas A. 2008. Evaluation of wheat (Triticum aestivum L.) genotypes under preand post-anthesis drought stress conditions. Journal of Agricultural Science Technology, 10 (2): 109-121

Sardans J., Peñuelas J. 2004. Increasing drought decreases phosphorus availability in evergreen Mediterranean forest. Plant and Soil, 267 (1-2): 367-377 http://dx.doi.org/10.1007/s11104-005-0172-8

Sinclair T. R., Jamieson P. D. 2006. Grain number, wheat yield, and bottling beer: an analysis. Field Crops Reserch, 98 (1): 60-67 http://dx.doi.org/10.1016/j.fcr.2005.12.006

Šlapakauskas V., Duchovskis P. 2008. Augalų produktyvumas. Lithuanian University of Agriculture, p. 124-148 (in Lithuanian)

Taiz L., Zeiger E. 2002. Plant physiology ( $3^{\text {rd }}$ ed.). Sunderland, USA, $690 \mathrm{p}$.
Tarakanovas P., Raudonius S. 2003. Agronominių tyrimų duomenų statistinè analizè taikant kompiuterines programas ANOVA, STAT, SPLIT-PLOT iš paketo SELEKCIJA ir IRRISTAT. Lithuanian University of Agriculture, $58 \mathrm{p}$. (in Lithuanian)

World reference base for soil resources. 2014. International soil classification system for naming soils and creating legends for soil maps. World Soil Resources Reports No. 106. FAO, Rome, $181 \mathrm{p}$.

Wu F. Z., Bao W. K., Li F. L., Wu N. 2008. Effects of water stress and nitrogen supply on leaves gas exchange and fluorescence parameters of Sophora davidii seedlings. Photosynthetica, 46 (1): 40-48

http://dx.doi.org/10.1007/s11099-008-0008-x

ISSN 1392-3196 / e-ISSN 2335-8947

Zemdirbyste-Agriculture, vol. 102, No. 3 (2015), p. 265-272

DOI 10.13080/z-a.2015.102.034

\title{
Aminorūgščių ịtaka azoto, fosforo ir kalio pokyčiams vasariniuose miežiuose drẻgmès trūkumo sąlygomis
}

\author{
I. Pranckietienė, E. Mažuolytė-Miškinè, V. Pranckietis, R. Dromantienė, G. Šidlauskas, \\ R. Vaisvalavičius
}

Aleksandro Stulginskio universitetas, Lietuva

\section{Santrauka}

Siekiant nustatyti skirtingų koncentracijų aminorūgščių ịtaką azoto, fosforo bei kalio dinamikai vasarinių miežių antžeminèje dalyje ir grūdų derlingumui drègmès trūkumo sąlygomis, vegetacinis eksperimentas atliktas Aleksandro Stulginskio universitete, paprastajame giliau glejiškame išplautžemyje. Eksperimento schema: A veiksnys - skirtingų koncentracijų aminorūgščių tirpalai: nepurkšta, purkšta vandeniu, purkšta $0,5,1,0,1,5$ bei $1,5 \%$ su mikroelementais ir 2,0 \% koncentracijos aminorūgščių tirpalais; B veiksnys - tręšimo aminorūgštimis laikas BBCH 21-23 ir BBCH 26-29 augimo tarpsniais. Dirvožemio drègnis augalu BBCH 21-49 tarpsniu kito nuo 14,5 iki 8,7 \%; tai vertinta kaip drėgmès trūkumas. Nustatyta, kad skirtingų koncentracijų aminorūgščių tirpalai, panaudoti vasariniams miežiams tręšti BBCH 21-23 arba $\mathrm{BBCH}$ 26-29 tarpsniais, esant drègmès trūkumui, esmingai didino azoto, fosforo bei kalio kiekius augaluose BBCH 26-29 ir BBCH 32-35 tarpsniais, palyginus su vandeniu nepurkštais augalais. Vanduo skatino azoto ịsisavinimą, ir daugeliu atvejų vandens įtaka buvo lygiavertė aminorūgščių įtakai. Dèl aminorūgščių ịtakos azoto kiekis antžeminejje vasarinių miežių dalyje nepasiekè optimalaus lygio, o fosforo kiekis BBCH 26-29 tarpsniu pasiekè optimalaus kiekio minimalią ribą. Esminis derlingumo priedas $\left(0,15-0,47 \mathrm{t} \mathrm{ha}^{-1}\right)$ gautas vasarinius miežius patręšus BBCH $21-23$ tarpsniu 1,0\% koncentracijos aminorūgščių tirpalu.

Reikšminiai žodžiai: augimo tarpsniai, dirvožemio armens drègnis, grūdų derlius, Hordeum vulgare, mineralinès mitybos elementai. 